Article

\title{
Mechanisms for Innovative-Driven Solutions in European Smart Cities
}

\author{
Stella Manika \\ Department of Planning and Regional Development, University of Thessaly, 38334 Volos, Greece; \\ smanika@uth.gr
}

Received: 3 May 2020; Accepted: 28 May 2020; Published: 1 June 2020

check for updates

\begin{abstract}
Innovative procurement is an important tool for smart cities to improve the effectiveness and efficiency of public services, especially in sectors such as smart living (for example, health conditions), smart mobility, or smart environment (with emphasis on waste and water management). The European Union (EU) public procurement legislative framework encourages the deployment of innovation by several means (including, inter alia, the introduction of competitive procedures promoting innovation, use of award criteria based on factors other than price, and the life-cycle approach) and sets the scene for a more strategic procurement for EU smart cities. Despite the proven benefits of innovative procurement, public authorities, driven mainly by their preference to follow traditional tender procedures under solely budgetary considerations, have hesitated to introduce innovation. The case study of Greece is examined, and it is concluded that despite the adopted policy measures that are conducive for mainstreaming innovation procurement, innovation procurement in Greece is at an early development stage. One of the reasons that hinder the application of innovation-oriented procedures by public purchasers is their insufficient knowledge of the available legal framework. The broad objective of this article is to outline the main innovation-friendly tools, as set out in the applicable European public procurement legislative framework that smart cities should adopt in order to make strategic use of innovative procurement.
\end{abstract}

Keywords: smart city; innovation; public procurement; European policies

\section{Introduction}

The role of public procurement as a policy instrument that stimulates innovation has been increasingly emphasized during the past years. From 2014, with the adoption of the EU legislative procurement package (see https://ec.europa.eu/growth/single-market/public-procurement/rules-imp lementation_en), there has been growing academic interest in innovative public procurement and subsequent rise of related policy measures in innovation policy agendas.

The total value of public procurement in the EU is estimated at around $14 \%$ of the EU gross domestic product (GDP) [1]. Aside from the primary purpose of public procurement to fulfill the needs and demands of public administration and citizens, public procurement can be an attractive instrument for fostering the objectives of EU innovation policies. By applying the appropriate procurement mechanisms strategically, procurement officials in cities can use their abundant purchasing power to drive innovation, promote urban growth and citizen well-being, and ultimately improve productivity, quality, and affordability of the procured services [2].

The concept of innovation in procurement includes (i) the attraction of innovative suppliers in the procurement process, (ii) the purchase of innovative products, and (iii) the adoption of innovative methods in the tender process itself.

There are several research literature streams on innovation in public procurement that emphasize its strategic nature as it achieves better results compared to other supply-related policies $[3,4]$. 
Several authors have explored the link between public procurement and innovation outcomes [5-7] and focused on the policy interventions that stimulate the use of innovation [8,9].

The literature in innovation in the context of public procurement has also dealt extensively with the role of institutions in the implementation of innovative initiatives [10], the risks associated with procuring innovative solutions [11], and the difficulties encountered by the suppliers to achieve innovation [12]. As a one-size-fits-all model cannot be applied to all procurement contexts, it is recommended that a framework be developed based on the nature of the goods and services procured, in order to explore the potential impacts upon markets [13]. Relevant research has also been conducted covering definitional and procedural issues related to innovation $[3,14,15]$.

Smart procurement can be a catalyst for local innovation in cities, offering innovative services that address local challenges (such as energy, mobility, and transport) and helping innovative suppliers to increase the technology readiness of their products. Smart cities can also benefit from innovative procurement in order to improve urban life through more sustainable, integrated solutions. In particular, innovative procurement could help develop electric car-sharing solutions, which would reduce emissions and noise in cities and free up urban space. It could also allow smart cities to better manage their public lighting infrastructure (with cost-effective modern lamp technology) and intelligent traffic management systems (to make roads safer and increase energy efficiency). Furthermore, in the midst of the COVID-19 outbreak crisis, innovative procurement could encourage the development of telemedicine and e-health tools using technology to deliver care at a distance. It could also foster the adoption of innovative digital health technologies (including establishing comprehensive data infrastructure, telemedicine, artificial intelligence for data analysis, innovative solutions to produce a vaccine with state-of-the-art technological equipment) that would help to improve measurability and predictability and provide innovative solutions for patient treatment.

Public procurement is a highly regulated activity at the EU level. European cities satisfy their need for new technologies, infrastructure, and services following public procurement rules while being under public scrutiny related to their mandate to manage taxpayer money wisely. However, traditional purchasing practices and complex procurement rules are often not suited to the purchase of innovative technologies and services. The revised European procurement rules of 2014 (in particular, Directive 24/2014/EU) have highlighted the crucial role of innovation as an important factor for smart, sustainable, and inclusive growth and broadened the possibility of public procurers to purchase innovation. Public procurers can, therefore, carry out procurements following competitive procedures such as competitive dialogue, competitive procedure with negotiation, innovation partnership, or based on the pre-commercial procurement exemption.

The European Commission has also provided guidance [16] on procuring options that support innovation. The interrelation between smart cities and innovative procurement is explained by the fact that smart cities, as environments of open and user-driven innovation for experimenting, have an enormous opportunity to spur innovation when they procure. With the aim to satisfy their complex procurement needs, smart cities have to follow forward-thinking strategies and engage in a constructive dialogue with the private sector, start-ups, and innovative SMEs, within the limits imposed by EU public procurement rules.

Despite the increased role of innovation in public procurement at the EU level and the availability of several procurement methods that foster innovation, EU public purchasers have hesitated to adjust their conventional procurement practices by introducing innovation-related elements. Greece is an example of an EU country where innovative procurement is at an early development stage, and several important elements to foster its further development are still missing. The preference of procurement officials to follow traditional procurement and their aversion to work with unproven ideas or unknown suppliers is considered a barrier that hinders innovative procurement. In addition, by proposing traditional payment schemes to the contractors and requesting strict economic and professional qualifications from tenderers (for example, a minimum required financial turnover as a qualification criterion), public authorities have failed to attract innovative players or newly founded firms and SMEs 
Apart from the risk-averse behavior of procurement officials in cities, another reason that prevents public buyers from capturing innovation is their lack of expertise and knowledge of innovative procurement processes. When in need of innovative purchasing, public authorities follow traditional procurement processes, considering that any other procuring method would require costly monitoring and further commercial skills that city services may not possess. Good knowledge of the available procurement practices and their appropriate use will support procurement officials in cities to make strategic use of innovative procurement and properly respond to the cities' specific needs.

Guided by the above considerations, this article provides an overview of the innovation-oriented provisions in the European Public Procurement legislative framework that smart cities can apply to satisfy their needs arising from technological developments and increased focus on sustainable and innovation-friendly public spending.

\section{Exploring the Innovation Procurement Concept and the Challenges Faced by Public Purchasers}

The term "innovation", as provided in the European Procurement Directive, emphasizes the high value of innovation as one of the main drivers of future growth of European cities:

"Innovation' means the implementation of a new or significantly improved product, service, or process, including but not limited to production, building or construction processes, a new marketing method, or a new organizational method in business practices, workplace organization, or external relations, inter alia, with the purpose of helping to solve societal challenges or to support the Europe 2020 strategy for smart, sustainable and inclusive growth;" (Article 2 (22) of the EU Public Procurement Directive 2014/24/EU).

Therefore, the EU Public Procurement Directive highlights that the purchase of innovative products and services can not only improve the quality of public services but also achieve economic, environmental, and societal benefits "in terms of generating new ideas, translating them into innovative products and services and thus promoting sustainable economic growth" (Recital 47 of the EU Public Procurement Directive 2014/24/EU).

The obvious benefit of introducing the element of innovation in public procurement refers mainly to cost-effectiveness. Even though existing technologies can be less costly than new technologies, innovative procurement can eventually lead to cost savings stemming from the life-cycle costs over the long-term and by "identifying the key process equipment components and determining the preferred vendor for specific equipment items, negotiating, bidding, or purchasing the equipment prior to the bidding of the project" [17]. Taking procurement decisions based on a long-term perspective on strategic development will eventually be more beneficial than focusing only on the lowest price. Given that the public buyers have the duty to provide citizens (taxpayers) with public-interest services of the best possible quality, they can benefit from receiving higher quality deliverables at a more competitive price (best value for money).

Apart from the benefit of cost optimization, public authorities can make use of the strategic potential of innovative procurement in order to modernize public services, following technological progress, especially in sensitive sectors of smart cities such as healthcare, waste and water treatment, urban planning, and education. Innovative procurement enables procurement officials in cities to get technologically innovative solutions developed according to their concrete needs [18]. The role of smart cities to open up procurement mechanisms to make them accessible to smaller innovative businesses allows them to reduce the gap between technological developments and citizens benefiting therefrom. Investing in innovation procurement also means new business opportunities for enterprises and the growth of start-ups and SMEs by having public buyers as customers. 
Despite the recognized value of innovative public procurement, many public authorities have hesitated to adjust their traditional procurement practices by introducing innovation-related requirements. Public purchasers still use traditional contract forms ("design-bid-build"), leading to low-quality and low-price products [19]. The most common barriers for the cities to capture innovation through public procurement are related to the inherent risk aversion of the public sector [20], lack of technical and managerial skills required to uptake new technologies, and market developments and political support [2]. Metcalfe and Georghiou [21] identified the challenges faced by cities that impede their capacity to embrace innovation in public procurement, including, inter alia, difficulties in identifying innovative opportunities, limited capacity to seize these opportunities, and lack of resources.

The risk-averse behavior of public authorities stems mainly from the public scrutiny related to their mandate to manage taxpayer money wisely, as they find it difficult to reassure public buyers that new technologies can deliver on their promises. Public purchasers prefer a structured procurement approach, guided mainly by budgetary considerations, where innovation is not the evident priority. An innovative procurement entails not only the risk of working with unknown suppliers but also additional costs compared to a traditional procurement process, including, inter alia, preliminary market consultation costs, negotiations, research and development, and staff training, which a public purchaser is not interested in undertaking $[19,22,23]$.

Government support can change the cities' averse mindset. Public procurement's link with broader policy objectives (growth of SMEs, job creation, social and environmental aspects) should be incentivized and highlighted at the national level. The State could intervene by setting innovation procurement as a mandatory objective or ensuring further financing that may cover the additional costs associated with innovation procurement. Innovation financing may also originate at the EU level from several available EU funding programs intended to support innovation procurement [24].

Another problem that affects the public buyer's capacity to use innovative procurement is the weak institutional setup. To face this challenge, a public sector reform (cultural and procedural) would be crucial in order to build up capacity, reduce the bureaucratic burden, and increase the overall efficiency and effectiveness of public procurement. Furthermore, insufficient knowledge of the legislative and regulative background is one of the main reasons that public buyers may decide to abstain from favoring innovation when producing and consuming goods and services. Offering specialized training and fostering a generally entrepreneurial culture can help to build the necessary capacity for innovation procurement at a manageable cost [25]. New management skills and innovation-orientated procurement strategy, with risk management approaches to procurement, should be further developed $[11,19,26,27]$.

Several EU member states have created national competence centers on innovative procurement that offer a variety of services to public procurers such as training, best practice examples, conferences, networking events, legal support, individual counseling, financial incentive schemes, and assistance in finding national and European funding [28].

\section{Innovation-Friendly Considerations in the European Public Procurement Framework}

At the European level, the applicable framework for public procurement is the principles of the Treaty of the Functioning of the European Union (TFEU-https://eur-lex.europa.eu/legal-cont ent/EN/TXT/PDF/?uri=CELEX:12012E/TXT\&from=EN) and the EU Public Procurement Directives of 2014. The framework opens up several opportunities for innovation, providing for specific innovation-friendly tender procedures while maintaining the basic requirements of the competition, transparency, equal treatment, and compliance with European State aid rules.

The existing tools available for public authorities to develop their procurement capacity and conduct innovative procurement, include flexible, competitive procedures where the public authority engages in a constructive dialogue with the tenderers. These procedures (competitive dialogue procedure and competitive procedure with negotiation) are mainly designed for technically and financially complex projects that require adaptation of readily available solutions of a particularly 
complex nature or where technical specifications cannot be established with sufficient precision (Article 26 (4) of the Directive 2014/24/EU).

The competitive dialogue (Article 30 of the Directive 2014/24/EU) is a two-phase tender procedure (dialogue phase and bidding phase) that allows a controlled interaction between the public purchaser and the bidders. Firstly, the public authority set out its needs and requirements in the contract notice. In the dialogue phase, the public authority may discuss all aspects of the contract with the bidders, including the economic conditions, and will continue the dialogue until it can identify the solutions which are capable of meeting its needs. When the dialogue phase is over, the bidders will submit their final tenders based on the solutions presented and specified during the dialogue phase.

During the bidding phase, the requirements will increasingly be specified, the technical details will be clarified, and possible uncertainties will be adjusted. The public authority will assess the tenders received based on the award criteria described in the contract notice (best price/quality ratio). The contracting authority is permitted to negotiate with the tenderer presenting the best price/quality ratio, but only to confirm financial commitments or other terms specified in the tender. Examples of the use of the competitive dialogue are the construction of social infrastructure such as schools, hospitals/other healthcare facilities, prisons, or for the conduct of research studies when the form of research outputs and the nature of research methodologies cannot be identified [29-32].

The competitive procedure with negotiation (Article 29 of the Directive 2014/24/EU) is a procedure under which public authorities, following the advertisement of the contract opportunity, enter into a negotiation with the shortlisted bidders who may be invited by the public authority to submit their initial tenders. The initial and all subsequent tenders submitted by shortlisted bidders will be the basis for negotiations with the public authority. This procedure may take place in successive stages to reduce the number of tenders to be negotiated by applying the award criteria specified in the contract notice. At the end of the negotiations, the public authority will ask the remaining tenderers to set a common deadline to submit any new or revised tenders. The final tenders are evaluated based on the most economically advantageous tender criterion.

These competitive procurement procedures allow for discussion with suppliers and innovators, with the view to developing a solution based on a better understanding of the specific needs and the ultimate goal of the procuring authority [33]. The main difference between these two procedures is that competitive dialogue is used when the procuring authority cannot define how to meet its needs technically, whereas the competitive procedure with negotiation is used when the specifications of the end-products/services can be delivered at a preliminary stage. Even though this structure provides more flexibility to develop innovative solutions, these processes require additional financial and human resources (for instance, a dedicated project team in the public authority will need to meet regularly with the tenderers and review their revised offers).

In addition to the above competitive procedures, the EU Public Procurement Directive, with the aim of encouraging the employment of innovation, introduces a new procurement procedure called the innovation partnership (Article 31 of the Directive 2014/24/EU). This procedure combines the "procurement of research and development with the subsequent acquisition of the resulting supplies, services or works in a single contract" (Recital 49 of the Directive 2014/24/EU). During this procedure, public authorities can negotiate with the suppliers/service providers during the multistage process (that starts) in order to comprehend the best way for demand to meet supply. The procedure starts with the selection of the most suitable partners to develop a new solution and ends with the selection of the partner that will provide the final solution.

The evident benefit arising from this procedure is that the purchase of innovative outcomes does not require a new competition under the public procurement rules. In a different case, the award to a bidder of the research and development contract would be interpreted as a potential advantage and would demotivate other potential tenderers from participating in the subsequent supply contract. This scenario would prevent the de facto competition whilst excluding such economic operators from the supply phase may be more lucrative [33]. 
Another available innovation-friendly procurement method, exempted from the Directives, is pre-commercial procurement (PCP). The PCP method is applied when, following market consultation, the public buyer concludes that there is no solution available to the market to satisfy the city's needs [34].

PCP consists of procuring research and development $(R \& D)$ services with several suppliers before commercialization and may include the development of prototypes or limited volumes of first products or services in the form of a test series. In contrast with the innovation partnership that combines both development and purchase elements, the acquisition of commercial volumes of the products or services resulting from the R\&D contract will be awarded following a separate competitive tendering process. This separate procurement and contractual relationship enables public purchasers to identify and avoid technological R\&D risks before committing to purchase the developed innovative solution for large-scale commercial roll-outs. Another important aspect related to the PCP is the considerable funding that R\&D services require for new technologically advanced solutions, such as those for smart cities [35]. This funding requirement may be met through cooperation among regional authorities (public-public cooperation).

Another procedure envisaged in the EU Public Procurement Directives that may be employed for procuring innovative solutions is the design contest (Articles 78-82 of the Directive 2014/24/EU). This competitive procedure, mostly used "in the fields of town and country planning, architecture and engineering or data processing", allows competition for the selection of a plan or design by a jury that judges the designs submitted (Recital 21 of the Directive 2014/24/EU). The outcome of the procedure may be the award of the design contract, prizes, or both. The Directive sets requirements on the constitution, scope, and operation of the jury, without setting a specific number of phases or stages to be followed. The element of innovation in this process originates from the flexibility provided to the participants when proposing the best solution for the needs described in the contest notice.

Apart from the competitive procedures that trigger innovation, the EU public procurement legislative framework includes explicit rules on crossborder joint procurement (Recital 73 and Article 12 of the Directive 2014/24/EU) that may engage public purchasers from the various EU member states in a constructive collaboration to make joint purchases. Therefore, public authorities may achieve their innovation- and demand-pooling-related objectives while sharing the risks associated with innovative projects and attract more risk capital. Further collaboration among European member states and cities can be developed by knowledge sharing and the exchange of best practices. Smart cities can certainly benefit from sharing experiences or relevant documentation and developing synergies via specific platforms [16].

Furthermore, considering the crucial role of social protection, health care, education, and urban planning, the Directives have provided for a simplified procurement system for awarding contracts for such services with the threshold of EUR 750,000, which is much higher than the threshold that applies to other services under the scope of the Directive. The award of other services is regulated by the Directives, but to a lesser degree ("light regime"-Article 74 and Annex XIV of the Directive 2014/24/EU), as the procuring authorities are given wide discretion in the organization of procurement procedures. However, as a minimum, it does require advertisement in the Official Journal of the European Union (OJEU) and compliance with the TFEU principles (transparency, equal treatment, and non-discrimination).

In the field of smart cities, the involvement of start-ups and SMEs in public procurement for innovation is considered essential, as they intensify competition by offering greater choices to the public purchasers with their skills and competencies to create innovative products [36]. From a sustainability and social perspective, encouraging the SMEs' involvement in public contracting contributes to the economic and social health of a region, creating jobs and fostering entrepreneurship and innovation throughout the wider economy [37-39]. 
Although the current rules allow for a variety of options for public contracting entities to ask for innovative solutions, the commercial interaction between the public sector and SMEs is limited. Some of the main reasons that hinder the SMEs from public contracting include the administrative burden in the tender procedures, the restrictive and rigorous qualification standards (high financial turnover requirements and professional experience) that cannot be met by SMEs or start-ups with own resource constraints, and the public purchaser's preference for large scale companies [40]. Given these barriers, it is not a surprise that SMEs are under-represented in public contracting [41,42].

With the view to stimulate the participation of SMEs, the Directives have relaxed the administrative and documentation requirements for the bidders by requesting a completed self-declaration template (European Single Procurement Document-ESDP, Article 59 of the Directive 2014/24/EU) at the time of submission of tenders. The full documentation will be requested only from the winning bidder. Bearing also in mind the financing constraints of the SMEs, the public purchaser can announce more flexible payment schemes in the contract notice, such as early, advance, or interim payments, to facilitate SME participation. Despite the public buyers' preference for large integrated contracts, they may also consider the option provided in the EU Public Procurement Directives to subdivide public contracts into lots, opening the way for SMEs to participate and foster the move to more open, interoperable solutions [25].

Innovation can also be triggered at the time of defining the subject matter of the contract to be awarded. The Directive state that "functional and performance-related requirements are also appropriate means to favour innovation in public procurement and should be used as widely as possible" (Recital 75 of the Directive 2014/24/EU). Therefore, due attention should be given at the technical specification stage, to avoid setting too specific and restrictive technical requirements which focus mainly on price. On the contrary, the public buyers are encouraged to develop functional requirements focusing on the desired performance (or the problem that needs to be solved) instead of describing the product that is to perform the function of prescribing a concrete solution.

This approach guarantees certain flexibility to bidders to provide innovative solutions in order to meet performance targets and reach the optimal performance. In addition to functional requirements, and in order to attract more competition, especially from start-ups and innovative SMEs, the procuring authorities may allow the use of variants (Article 45 of the Directive 2014/24/EU), meaning the parallel submission of traditional and alternative innovative solutions, as long as they comply with the minimum requirements. The tender documents should clarify whether a tenderer can submit variants on their own or as a complement to a tender only. The use of different formulas may create some difficulties when evaluating the variants; however, this can be solved when variants are evaluated based on functional requirements and award criteria related to performance, cost-effectiveness, and life-cycle costs.

Another major step towards innovative procurement is the introduction of the concept of the most economically advantageous tender (MEAT) award criterion (Article 67 of the Directive 2014/24/EU) in an attempt from the legislator to ensure better value for money and higher quality of the products, work, and services procured. To identify the most economically advantageous tender, the contract award decision should not be based solely on criteria other than the price. Qualitative criteria should, therefore, be accompanied by a cost criterion that could, at the choice of the contracting authority, "be either the price or a cost-effectiveness approach such as life-cycle costing" (Recital 92 of the Directive 2014/24/EU).

The life-cycle cost (LCC; Article 68 of the Directive 2014/24/EU) is a tool for assessing the total cost performance of a product over time, including the acquisition, maintenance, and disposal costs, improving awareness of total costs and helping to evaluate competing options. It encourages public authorities to consider in their purchasing decisions not only by the price of the acquisition but also the costs related to the full life-cycle of the products. "This means internal costs, such as research to be carried out, development, production, transport, use, maintenance, and end-of-life disposal costs but can also include costs imputed to environmental externalities, such as pollution caused by extraction of the raw materials used in the product or caused by the product itself or its manufacturing, provided they can be monetized and 
monitored" (Recital 96 of the Directive 2014/24/EU). For some products (such as furniture) considering only the price factor might be a correct approach, but for other products (such as irrigation systems) the purchase price represents only a small part of the total costs that may include costs related to the use and maintenance of the product [43].

The European Commission has provided for a methodology (the LCC methodology) that can be applied at different stages of the procurement process. The public purchaser can introduce the LCC element when drafting the technical specifications that can be drawn up based on "performance criteria linked to the life cycle and the sustainability of the production process of the works, supplies and services" (Recital 74 of the Directive 2014/24/EU). In addition, LCC methodology can be considered at the award stage by including quality and life-cycle costing requirements as the main criteria in the award process, provided that it is foreseen in the relevant bidding documents. In light of the above, it could be concluded that bids with innovative elements may be awarded more points in the light of their long-term financial benefits [44]. Given the complexity of LCC methodology, the effectiveness of using an LCC approach should be given due consideration by employing a joint appraisal from legal, economic, and financial perspectives, a section that may be divided by subheadings. It should provide a concise and precise description of the experimental results, their interpretation, as well as the experimental conclusions that can be drawn.

\section{Case of Greece}

The Greek urban structure is characterized by the primary role of the metropolitan urban areas of Athens and Thessaloniki. Roughly half of the population of Greece (approximately 10.7 million) is concentrated in these two cities, with Athens accorded the lion's share (approximately 4 million). There is a number of much smaller cities (under 200,000 inhabitants) characterized by the typical morphology (streets, squares, city blocks) of modern Greek cities as a result of post-war housing development patterns in Greece [45]. As a consequence of such rapid urbanization, Greek rural areas are depopulating at an alarming pace, which highlights the necessity to revitalize rural services through digital and social innovation and subsequently adopt the concept of the smart village [46]. Furthermore, the recent sovereign debt crisis and the implemented policy measures have generated disincentives for investment, without generating growth and without improving the competitiveness of the Greek industry [47]. Therefore, unemployment, social innovation, adoption of strategies that contribute to smart city development [48], urban shrinkage or resilience, and SME competitiveness are some of the key challenges Greek cities are looking into [49].

Innovation procurement in Greece is mainly regulated by Law no. 4412/2016 on "Public works, supplies, and service contracts", which entered into force on 1 August 2016. This national legislation transposed the European Procurement Directives 2014/24 (Classical Procurement Directive) and 2014/25/EU (Utilities Procurement Directive). The main regulatory actors in the field of public procurement are

- The Government Council for Economic Policy, which approves the Action Plan for National Procurement Strategy;

- The General Directorate of Public Procurements (within the Ministry of Development), which is responsible for public supplies and services;

- the General Secretariat of Infrastructure, responsible for works procurement;

- National Central Authority for Procurements in Health, responsible for procurements in the health sector;

- The Hellenic Single Public Procurement Authority (SPPA), which monitors and evaluates the procurement decisions of public authorities;

- The National Central Purchasing Bodies. 
Innovation procurement is enabled and promoted by a number of policy documents and programs, such as the Greek National Strategy for Research and Development, the National Digital Strategy 2016-2021, and the Greek Smart Specialization Strategy. In the benchmarking of national innovation procurement policy frameworks across Europe (30 countries analyzed), the European Commission scored Greece in the 14th position. Despite Greece's willingness to implement policy measures to mainstream innovation procurement, this effort remains at "an early development stage, and most important elements to foster its development are still missing (e.g., capacity building and assistance, action plan, monitoring system, spending target, financial and other incentives for public procurers, etc.)." [50]. As indicated in Table 1 below, the innovation-friendly procedures reflect a small amount (EUR 31,339,020) compared to the total value of public procurement (EUR 6,500,928,819) in Greece for 2019. A similar pattern is observed for the first trimester of 2020 (Table 2).

\section{Conclusions}

Public procurement of innovative goods and services is an important tool for smart cities to improve the effectiveness of public services and address their needs (e.g., mobility, health, environment, security, and safety) while helping to create jobs and boost the competitiveness of corporates and SMEs. Given the significant purchasing power of European public authorities, the latter can play an important role in the promotion of innovation by integrating innovative considerations in the development of their procurement strategies. However, the application of procurement rules not suitable to the concrete needs of the procuring authority may upend a smart city project and represent a significant obstacle to accelerate smart cities' growth.

Risk-averse behavior triggered by the need for public bodies to provide public services of increased quality and efficiency, weak institutional setup, and limited experience with innovation-oriented procedures impede public buyers in smart cities from introducing innovation in their procurements. The examined case of Greece has shown that despite the adopted policy measures and legislative acts, innovation procurement in Greece is at an early development stage. 
Table 1. Number and cost of contracts per type of procurement procedure (1 January 2019-31 December 2019).

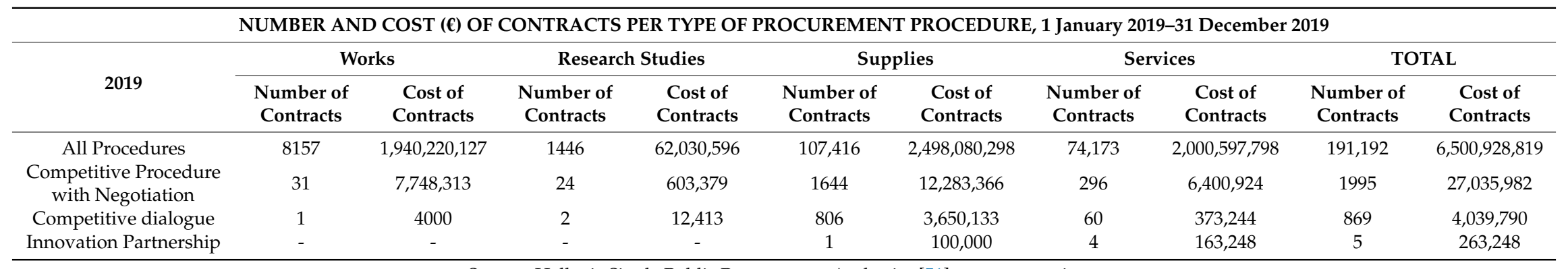

Source: Hellenic Single Public Procurement Authority [51], own processing.

Table 2. Number and cost of contracts per type of procurement procedure (1 January 2020-31 March 2020).

\begin{tabular}{|c|c|c|c|c|c|c|c|c|c|c|}
\hline \multicolumn{11}{|c|}{ NUMBER AND COST (€) OF CONTRACTS PER TYPE OF PROCUREMENT PROCEDURE, 1 January 2020-31 March 2020} \\
\hline \multirow[b]{2}{*}{$1 / 1 / 2020-31 / 3 / 2020$} & \multicolumn{2}{|c|}{ Works } & \multicolumn{2}{|c|}{ Research Studies } & \multicolumn{2}{|c|}{ Supplies } & \multicolumn{2}{|c|}{ Services } & \multicolumn{2}{|c|}{ TOTAL } \\
\hline & $\begin{array}{l}\text { Number of } \\
\text { Contracts }\end{array}$ & $\begin{array}{c}\text { Cost of } \\
\text { Contracts }\end{array}$ & $\begin{array}{l}\text { Number of } \\
\text { Contracts }\end{array}$ & $\begin{array}{c}\text { Cost of } \\
\text { Contracts }\end{array}$ & $\begin{array}{l}\text { Number of } \\
\text { Contracts }\end{array}$ & $\begin{array}{c}\text { Cost of } \\
\text { Contracts }\end{array}$ & $\begin{array}{l}\text { Number of } \\
\text { Contracts }\end{array}$ & $\begin{array}{c}\text { Cost of } \\
\text { Contracts }\end{array}$ & $\begin{array}{l}\text { Number of } \\
\text { Contracts }\end{array}$ & $\begin{array}{c}\text { Cost of } \\
\text { Contracts }\end{array}$ \\
\hline All procedures & 1063 & $280,549,493$ & 219 & $5,651,442$ & 20,088 & $497,675,793$ & 13,306 & $397,611,090$ & 34,676 & $1,181,487,818$ \\
\hline $\begin{array}{l}\text { Competitive Procedure } \\
\text { with Negotiation }\end{array}$ & 13 & $2,158,930$ & 2 & 39,196 & 1312 & $7,866,684$ & 78 & $4,502,661$ & 1405 & $14,567,471$ \\
\hline Competitive dialogue & 0 & 0 & 0 & 0 & 1162 & $5,326,161$ & 27 & 145,977 & 1189 & 5472,138 \\
\hline Innovation Partnership & 0 & 0 & 0 & 0 & 3 & 25,924 & 0 & 0 & 3 & 25,924 \\
\hline
\end{tabular}

Source: Hellenic Single Public Procurement Authority [51], own processing. 
Apart from the PCP model, which has been widely followed, the European legislative framework provides for other innovation-friendly procurement provisions that have not been adopted by public authorities in an equal manner. Good knowledge of the available public procurement practices and tools offered by the European policies and rules will support both public buyers in smart cities and innovative SMEs in gradually benefitting from the appropriate procurement mechanisms. The article provides an overview of the innovation-friendly procedures and provisions set out in the EU procurement framework.

Apart from the incorporation of the aforementioned methods in the procurement practices of public purchasers, additional steps should be taken towards this direction. In particular, at the national level, incentives and support from the State will encourage smart cities to embrace innovation and change their mindset. The setup of national competence centers with an updated library of innovative technical solutions can also be considered as a crucial step to mainstream innovation procurement.

Knowledge sharing, exchange of best practices via training and workshops among European member states and city authorities, and developing synergies via specific platforms should be encouraged. The establishment of sustainable partnerships among the main stakeholders from the private sector and research and policy groups, with the aim of achieving an alignment of local, regional, and European policy levels and resources, is also recommended. Furthermore, the development of urban logistics applications, innovative logistics management software, ICT tools, and digital solutions will allow city authorities to better coordinate and, hence, optimize their purchasing patterns (modeling, prediction for better planning, data). A public sector reform (cultural and procedural) would be crucial in order to build up capacity, reduce the bureaucratic burden, and develop an innovative ecosystem across the city and among its suppliers. Therefore, smarter approaches to public procurement should be further developed and widely adopted. Public purchasers should consult the market before tendering in order to identify what is available on the market and involve it in the city's procurement requirements. Public authorities that recognize the failure of traditional contracting process to attract innovators, but hesitate to conduct an innovative procurement process, may focus on the acquisition of limited prototypes and/or test products developed as a first step to purchasing innovative solutions. The acquisition of a larger volume of resulting end solutions on a commercial scale will follow after checking their technical and economic feasibility. Smart cities should, hence, encourage dialogue with the private sector and cultivate an innovation ecosystem across the city that will allow city services to collaborate closely with suppliers, with the view to developing future innovative solutions.

Funding: This research is co-financed by Greece and the European Union (European Social Fund (ESF)) through the Operational Programme "Human Resources Development, Education and Lifelong Learning" in the context of the project "Reinforcement of Postdoctoral Researchers-2nd Cycle" (MIS-5033021), implemented by the State Scholarships Foundation (IK $\Upsilon$ ).

Conflicts of Interest: The author declares no conflict of interest.

\section{References}

1. Single Market Scoreboard Report by the European Commission (2018). Available online: https://ec.europa.eu /internal_market/scoreboard/performance_per_policy_area/public_procurement/index_en.htm (accessed on 2 May 2020).

2. OECD. Public Procurement for Innovation: Good Practices and Strategies; OECD Public Governance Reviews; OECD Publishing: Paris, France, 2017. [CrossRef]

3. Edler, J.; Georghiou, L. Public procurement and innovation-Resurrecting the demand side. Res. Policy 2007, 36, 949-963. [CrossRef]

4. Geroski, P.A. Procurement policy as a tool of industrial policy. Int. Rev. Appl. Econ. 1990, 4, 182-198. [CrossRef] 
5. Aschhoff, B.; Sofka, W. Innovation on demand-Can public procurement drive market success of innovations? Res. Policy 2009, 38, 1235-1247. [CrossRef]

6. Guerzoni, M.; Raiteri, E. Demand-side vs. supply-side technology policies: Hidden treatment and new empirical evidence on the technology policy mix. Res. Policy 2015, 44, 726-747. [CrossRef]

7. Georghiou, L.; Edler, J.; Uyarra, E.; Yeow, J. Policy instruments for public procurement of innovation: Choice, design and assessment. Technol. Forecast. Soc. Chang. 2014, 86, 1-12. [CrossRef]

8. Dalpé, R.; Debresson, C.; Xiaoping, H. The public sector as first user of innovations. Res. Policy 1992, 21, 251-263. [CrossRef]

9. Edquist, C.; Hommen, L.; Tsipouri, L.J. Public technology procurement and innovation. Econ. Sci. Technol. Innov. 2000, 16. [CrossRef]

10. Rolfstam, M. Public procurement as an innovation policy tool: The role of institutions. Sci. Public Policy 2009, 36, 349-360. [CrossRef]

11. Kalvet, T.; Lember, V. Risk management in public procurement for innovation: The case of Nordic-Baltic Sea cities. Innov. Eur. J. Soc. Sci. Res. 2010, 23, 241-262. [CrossRef]

12. Uyarra, E.; Edler, J.; Garcia-Estevez, J.; Georghiou, L.; Yeow, J. Barriers to innovation through public procurement: A supplier perspective. Technovation 2014, 34, 631-645. [CrossRef]

13. Uyarra, E.; Flanagan, K. Understanding the innovation impacts of public procurement. Eur. Plan. Stud. 2010, 18, 123-143. [CrossRef]

14. Hommen, L.; Rolfstam, M. Public procurement and innovation: Towards a taxonomy. J. Public Procure. 2009, 9, 17-56. [CrossRef]

15. Obwegeser, N.; Müller, S.D. Innovation and public procurement: Terminology, concepts, and applications. Technovation 2018, 74, 1-17. [CrossRef]

16. European Commission-Analyzing the Potential for Wide Scale Roll-Out of Integrated SCC Solutions. Public Procurement Models for SCC Solutions (2016). Available online: https://eu-smartcities.eu/sites/de fault/files/2017-09/D8.2_Public\%20procurement\%20models\%20for\%20SCC\%20solutions.pdf (accessed on 2 May 2020).

17. Jeffcoat, S.; Lavinder, S.; Swaim, P. Innovative Procurement Methods or Process Equipment at Water Treatment Facilities to Offset Escalating Construction Costs; American Water Works Association: Denver, CO, USA, 2005.

18. European Commission. Communication to the European Parliament, the Council, the European Economic and Social Committee and the Committee of the Regions. Pre-commercial Procurement: Driving Innovation to Ensure Sustainable High Quality Public Services in Europe \{SEC(2007) 1668\}; European Commission: Brussels, Belgium, 2007.

19. Boes, H.; Dorée, A. Public procurement of local authorities in the Netherlands: A case of breaking tradition for a more strategic approach? In Proceedings of the ARCOM Conference, Cardiff, UK, 1-3 September 2008; pp. 477-486.

20. Rolfstam, M. An institutional approach to research on public procurement of innovation. Innov. Eur. J. Soc. Sci. Res. 2012, 25, 303-321. [CrossRef]

21. Metcalfe, S.; Georghiou, L. Equibrium and Evolutionary Foundations of Technology Policy; CRIC Discussion Paper, No 3; Centre for Research on Innovation and Competition, University of Manchester: Manchester, UK, 1997.

22. Eadie, R.; McKeown, C.; Anderson, K. The impact of recession on construction procurement routes. Int. J. Procure. Manag. 2013, 6, 24. [CrossRef]

23. Yeow, J.; Edler, J. Innovation procurement as projects. J. Public Procure. 2012, 12, 472-504. [CrossRef]

24. European Commission-Research and Innovation, Funding Opportunities. Available online: https://ec.europa.eu/research/participants/portal/desktop/en/opportunities/h2020/ftags/innov_proc. html\#c,topics=callStatus/t/Forthcoming/1/1/0/default-group\&callStatus/t/Open/1/1/0/default-group\&callS tatus/t/Closed/0/1/0/default-group\&+identifier/desc (accessed on 3 May 2020).

25. European Commission. Guidance on Public Procurement of Innovation; European Commission: Brussels, Belgium, 2018; p. 3051.

26. Klingler, F.; Edberg, J.; McMahon, M.; Lockhart, S.; Graboske, K. Balancing innovation, risk and cost: Innovative procurement approach for sewer tunnel rehabilitation. In North American Tunneling: 2014 Proceedings; Society for Mining, Metallurgy, and Exploration (SME): Englewood, CO, USA, 2014; pp. 618-624. 
27. Lember, V.; Kattel, R.; Kalvet, T. Quo vadis public procurement of innovation? Innovation 2015, $28,403-421$. [CrossRef]

28. European Commission, Procure2innovate: European Network of Competence Centres for Innovation Procurement. Available online: https://cordis.europa.eu/project/id/780192 (accessed on 5 May 2020).

29. Arrowsmith, S.; Treumer, S. Competitive Dialogue in EU Procurement; Cambridge University Press: Cambridge, UK, 2012.

30. Treumer, S.; Uyarra, E. Competitive dialogue and contractual design fostering innovation and needs analysis Dialogue. In Applied Law and Economics of Public Procurement; Piga, G., Treumer, S., Eds.; Routledge: London, UK, 2013; pp. 13-27.

31. OECD. What are the Public Procurement Procedures and When Can They Be Used? SIGMA Public Procurement Briefs, No. 10; OECD Publishing: Paris, France, 2010; Available online: https://doi.org/10.1787/5js4wzv53043 -en (accessed on 5 April 2020).

32. Haugbølle, K.; Pihl, D.; Gottlieb, S.C. Competitive Dialogue: Driving Innovation Through Procurement? Procedia Econ. Financ. 2015, 21, 555-562. [CrossRef]

33. Arrowsmith, S. The Law of Public and Utilities Procurement; Sweet and Maxwell: London, UK, 2014 ; Volume 1.

34. European Commission, Pre-Commercial Procurement (2015). Available online: https://ec.europa.eu/digital-s ingle-market/en/pre-commercial-procurement (accessed on 2 May 2020).

35. Ojasalo, J.; Holopainen, K.M. Challenges in using pre-commercial procurement (PCP) for enhancing innovation for cities: Results from an empirical study on smart cities. In Proceedings of the EDULEARN16 Proceedings, 8th International Conference on Education and New Learning Technologies, Barcelona, Spain, 4-6 July 2016; pp. 6786-6798. [CrossRef]

36. Woldesenbet, K.; Ram, M.; Jones, T. Supplying large firms: The role of entrepreneurial and dynamic capabilities in small businesses. Int. Small Bus. J. 2012, 30, 493-512. [CrossRef]

37. Walker, H.; Preuss, L. Fostering Sustainability through Sourcing from Small Businesses: Public Sector Perspectives. J. Clean. Prod. 2008, 16, 1600-1609. [CrossRef]

38. Lindgreen, A.; Swaen, V.; Maon, F.; Walker, H.; Brammer, S. Sustainable procurement in the United Kingdom public sector. Supply Chain Manag. Int. J. 2009, 14, 128-137.

39. Flynn, A.; Davis, P. Explaining sme participation and success in public procurement using a capability-based model of tendering. J. Public Procure. 2017, 17, 337-372. [CrossRef]

40. Loader, K. Is Public Procurement a Successful Small Business Policy Support? A Review of the Evidence. Environ. Plan. C Gov. Policy 2013, 31,39-55. [CrossRef]

41. Clark, M.; Moutray, C. The Future of Small Businesses in the US Federal Government Marketplace. J. Public Procure. 2004, 4, 450-470. [CrossRef]

42. Nicholas, C.; Fruhmann, M. Small and Medium-sized Enterprises Policies in Public Procurement: Time for a Rethink? J. Public Procure. 2014, 14, 328-360. [CrossRef]

43. Rüdenauer, I.; Dross, M.; Eberle, U.; Gensch, C.O.; Graulich, K.; Hünecke, K.; Koch, Y.; Möller, M.; Quack, D.; Seebach, D.; et al. Costs and Benefits of Green Public Procurement in Europe; Öko-Institut e.V.: Freiburg, Germany; ICLEI-Local Governments for Sustainability: Bonn, Germany, 2007; Available online: www.icleieurope.org/index.php?id=gppcb (accessed on 8 April 2020).

44. European Commission. Life-Cycle Costing. 2016. Available online: http://ec.europa.eu/environment/gpp/lcc .htm (accessed on 10 April 2020).

45. Gospodini, A. Portraying, classifying and understanding the emerging landscapes in the post-industrial city. Cities 2006, 23, 311-330. [CrossRef]

46. Visvizi, A.; Lytras, M.D. It's Not a Fad: Smart Cities and Smart Villages Research in European and Global Contexts. Sustainability 2018, 10, 2727. [CrossRef]

47. Visvizi, A. The crisis in Greece and the EU-IMF rescue package: Determinants and pitfalls. Acta Oeconomica 2012, 62, 15-39. [CrossRef]

48. Visvizi, A.; Lytras, M. Rescaling and refocusing smart cities research: From mega cities to smart villages. J. Sci. Technol. Policy Manag. (Jstpm) 2018. [CrossRef]

49. Manika, S. Economic Crisis, Shrinking Greek Cities and Urban Regeneration Policies; Department of Planning and Regional Development, University of Thessaly: Volos, Greece, 2018. 
50. European Commission. "The Strategic Use of Innovation Procurement in the Digital Economy" SMART 2016/0040, Performed by PwC. 2019. Available online: https:/ec.europa.eu/digital-single-market/en/ news/benchmarking-national-innovation-procurement-policy-frameworks-across-europe (accessed on 15 April 2020).

51. Hellenic Single Public Procurement Authority (2020). Available online: https://www.eaadhsy.gr/ (accessed on 9 April 2020). 